\title{
Influence of Temperature, Moisture, and Light Conditions on the Germination of Seeds of Erythronium japonicum Decne
}

\author{
Yumiko Kanazawa, Junko Abe, Shinji Kobayashi, Kazue Shibuya, Kojiro Suzuki \\ Department of Landscape Architecture Science, Faculty of Regional Environmental Science, Tokyo University \\ of Agriculture, Tokyo, Japan \\ Email:kojiros@nodai.ac.jp
}

How to cite this paper: Kanazawa, Y., Abe, J., Kobayashi, S., Shibuya, K., \& Suzuki, K. (2018). Influence of Temperature, Moisture, and Light Conditions on the Germination of Seeds of Erythronium japonicum Decne. Open Journal of Forestry, 8, 105-116. https://doi.org/10.4236/ojf.2018.81008

Received: December 10, 2017

Accepted: January 13, 2018

Published: January 16, 2018

Copyright ( $) 2018$ by authors and Scientific Research Publishing Inc. This work is licensed under the Creative Commons Attribution International License (CC BY 4.0).

http://creativecommons.org/licenses/by/4.0/

(c) (i) Open Access

\begin{abstract}
Erythronium japonicum is a representative species of spring ephemeral, forest floor plants in substitution forests in Japan. Seed germination tests were conducted to observe the effects of temperature, light, and moisture content on the germination of E. japonicum. E. japonicum seeds did not germinate at constant temperatures of $5^{\circ} \mathrm{C}, 10^{\circ} \mathrm{C}, 15^{\circ} \mathrm{C}, 20^{\circ} \mathrm{C}$, or $25^{\circ} \mathrm{C}$. Seeds germinated at $5^{\circ} \mathrm{C}$ and $10^{\circ} \mathrm{C}$ after storage at $20^{\circ} \mathrm{C}$ for 1 or 2 months. Seed germinability was affected by desiccation to only $40 \%$ moisture content. Seeds germinated well in both light and dark conditions. Conditions under the leaf litter layer showed unique characteristics of temperature, light, and moisture content. The temperature was around $20^{\circ} \mathrm{C}$ under the leaf litter layer, even though it was $30^{\circ} \mathrm{C}$ above. The moisture content under the leaf litter layer was higher than that above. The leaf litter blocked out the sunlight. The temperature of $20^{\circ} \mathrm{C}$ necessary for $E$. japonicum germination occurred below, but not above, the leaf litter layer. The avoidance of decreasing in germinability from reduced seed moisture content in a short time is consistent with the high moisture conditions under the leaf litter layer. The leaf litter layer plays an important role in providing optimal conditions of temperature, light, and moisture content for the germination of E. japonicum seeds.
\end{abstract}

\section{Keywords}

Erythronium japonicum, Leaf Litter Layer, Life History, Seed Germination, Spring Ephemeral

\section{Introduction}

Satoyama woods are located in the suburbs between mountainous and urban 
areas in Japan. Until the 1950s, people traditionally used many plants from Satoyama woods (Morimoto, 2011; Yokohari \& Bolthouse, 2011). For example, Quercus acutissima and Q. serrata were used as charcoal fuel, and mother wood to cultivate shiitake (mushrooms). Q. dentata was used for covering food, or caching. Abies firma was used for furniture. Erythronium japonicum and Allium victorialis var. platyphyllum were used for food. Their leaves were used for organic fertilizer or fuel. Satoyama woods have not been used as natural resources since people began using oil fuels as energy sources and their general lifestyles changed. The area of open space with plants has decreased at a rapid pace owing to unrecognized economical aspects (Iida \& Nakashizuka, 1995; Stéphanie et al., 2007), and the abandoned Satoyama woods are no longer balanced between succession and felling for human uses. Substitution forests consist of deciduous trees that have been replaced by evergreen broadleaved forest (Nakajima et al., 2017). Substitution forest in Satoyama woods has decreased the populations of forest floor plants (Nakajima et al., 2016).

Forest floor plants that were used as foods or habitats in previous years are mainly used for tourism now. However, open spaces with many plants and animals have additional functions related to recreation, air pollution, disaster prevention, evacuation, habitats, and biodiversity. Forest floor plants are not only useful for the conservation of native plants, but also provide beautiful landscapes in urban areas or suburbs.

E. japonicum has a unique arrangement of leaves and flowers and is a spring ephemeral, forest floor plant (Kawano, 2004). E. japonicum had been used as a food source, and is very popular among the local people. However, the area of distribution of $E$. japonicum has decreased due to development of housing and other buildings, or abandonment of the subsistence forest. Numbers of E. japonicum have decreased year on year, and it is now designated as Vulnerable (VU), which includes species at increased risk of extinction in 16 prefectures in Japan at RDB (Association of Wildlife Research and EnVision, 2007).

This study was conducted to identify favorable conditions for the propagation of $E$. japonicum by examining seed germination tests in relation with temperature, light, and moisture content.

\section{Materials and Methods}

\subsection{Seeds Selection}

Seeds used for germination tests at different temperatures and light conditions were collected on June 4, 2001 [Fukushima 2001], and May 31, 2002 [Fukushima 2002] at Koriyama city, Fukushima Prefecture ( $\left.37^{\circ} 24^{\prime} 46.31^{\prime \prime}, 140^{\circ} 16^{\prime} 22.83^{\prime \prime}\right)$, and June 20, 2005 [Akita 2005], and June 3, 2007 [Akita 2007] at Nishiki town, Senboku city, Akita Prefecture (39 $\left.41^{\prime} 16.57^{\prime \prime}, 140^{\circ} 33^{\prime} 1.80^{\prime \prime}\right)$, respectively. Seeds used for germination tests of moisture content were [Akita 2007] and collected on June 7, 2008 [Akita 2008] at Nishiki town, Senboku city, Akita Prefecture, and June 5, 2008 [Fukushima 2008] at Koriyama city, Fukushima Prefecture. 
The main vegetation where E. japonicum grows at Koriyama city, Fukushima Prefecture was Quercus serrata, Q. acutissima, Styrax japonica, Ilex macropoda, Pinus densiflora, Swida controversa, Acer amoenum var. matsumurae, and Zelkova serrata. The area of Nishiki town, Senboku city, Akita Prefecture was the main field for Castanea crenata fruit collection. The soil types of both Fukushima Prefecture and Akita Prefecture were same as brown forest soil.

\subsection{Germination Tests in the Laboratory}

Thirty seeds were placed in 9-cm diameter glass dishes with two sheets of filter paper soaked in $4 \mathrm{ml}$ tap water. Dishes were placed in individual chambers (NK System Co.) maintained at $10^{\circ} \mathrm{C}, 15^{\circ} \mathrm{C}, 20^{\circ} \mathrm{C}$, or $25^{\circ} \mathrm{C}$ and illuminated using a fluorescent lamp on a 12 -h light cycle $\left(28.7 \mu \mathrm{mol} / \mathrm{m}^{2} / \mathrm{S}\right)$. Seed germination tests were conducted with three replicates. Germinated seeds were recorded and removed from the dish each week and the percentage of germinated seeds was calculated until germination ceased (1-year maximum). Surface sterilization for the seed germination tests did not do.

Temperature, light, and moisture content differs between above and below the leaf litter layer (Suzuki, 2006). In this study, to observe seed germination at different temperatures, seed germination tests were conducted at $10^{\circ} \mathrm{C}, 15^{\circ} \mathrm{C}, 20^{\circ} \mathrm{C}$, and $25^{\circ} \mathrm{C}$ immediately after seed collection and after storage at room temperature $\left(20^{\circ} \mathrm{C}-25^{\circ} \mathrm{C}\right)$ for 1 to 3 months at first. These seeds were stored in wetted perlite after being put in a net bag $(10 \mathrm{~cm} \times 10 \mathrm{~cm})$ in an unglazed pot $(23 \mathrm{~cm}$ diameter, $20 \mathrm{~cm}$ depth). Seed germination tests were conducted under light conditions in same above individual chambers (NK System Co.) with seeds [Fukushima 2001]. One of the seeds was stored in dry conditions to observe the influence of desiccation on seed germination, as below.

Secondly, seeds [Fukushima 2002] were used in germination tests at $10^{\circ} \mathrm{C}$, $15^{\circ} \mathrm{C}, 20^{\circ} \mathrm{C}$, and $25^{\circ} \mathrm{C}$ immediately after seed collection, after storage at $5^{\circ} \mathrm{C}$ or $20^{\circ} \mathrm{C}$ for 3 months, and after storage at $20^{\circ} \mathrm{C}$ for 3 months followed by $5^{\circ} \mathrm{C}$ for 3 months under light conditions. The seeds were stored in wet conditions, packed in polyethylene bags for 1 to 3 months. One of the seeds was stored in dry conditions until desiccated to $16 \%$ M.C. (moisture content) to observe the influence of desiccation on germination, as below.

Thirdly, seed germination tests were conducted at a monitoring temperature representing the soil above the leaf litter layer $\left(30^{\circ} \mathrm{C}\right.$ or higher) for 2 months immediately after seed collection on [Akita 2005]. The monitoring temperature followed Suzuki \& Kawano (2010), who showed that temperature above the leaf litter layer occasionally reached over $30^{\circ} \mathrm{C}$; however, temperature below the leaf litter layer was more constant at approximately $22.5^{\circ} \mathrm{C}$.

During one seed germination tests, we looked the cross sections of seeds to observe embryo development after seed collection, and calculate the ratio of embryo to endosperm. The seeds used were [Akita 2007], and stored at $20^{\circ} \mathrm{C}$ for 1 month, followed by $10^{\circ} \mathrm{C}$ for 1 month, and $5^{\circ} \mathrm{C}$ under light condition. To observe the cross sections of seeds, we cut 10 samples at intervals of 2 weeks and took pictures using a 
stereoscopic microscope (Nikon SMZ800, Tokyo, Japan). Ratio of area of embryo to endosperm was calculated by measuring area with planimeter.

Fourthly, germination tests under different light conditions were conducted using seeds [Akita 2007]. Glass dishes were used for light conditions, and stainless-steel dishes were used for dark conditions, respectively. The germination tests were done at $5^{\circ} \mathrm{C}$ after $20^{\circ} \mathrm{C}$ for 1 month and $10^{\circ} \mathrm{C}$ for 1 month, or $10^{\circ} \mathrm{C}$ after $20^{\circ} \mathrm{C}$ for 1 month only. When we moved seeds to $5^{\circ} \mathrm{C}$ or $10^{\circ} \mathrm{C}$ from storage conditions, seeds that had changed from brown to black, or seeds that were empty were discarded. After seed germination, we continued to observe the growth of cotyledons at monitoring temperatures for natural conditions as leaf litter layer at forest floor from $7.5^{\circ} \mathrm{C}$ to $2.5^{\circ} \mathrm{C}$.

Fifthly, observe the effect of desiccation on germination, germination rates of seeds dried at room temperature were compared with non-desiccated seeds that were [Fukushima 2001] and [Fukushima 2002]. Seeds [Fukushima 2001] were tested at $10^{\circ} \mathrm{C}, 15^{\circ} \mathrm{C}, 20^{\circ} \mathrm{C}$, and $25^{\circ} \mathrm{C}$ after seed desiccation and compared with seeds stored in wet conditions in a polyethylene bag. Seeds [Fukushima 2002] were also used for germination tests at $5^{\circ} \mathrm{C}, 10^{\circ} \mathrm{C}, 15^{\circ} \mathrm{C}$, and $20^{\circ} \mathrm{C}$ after storage at $20^{\circ} \mathrm{C}$ for 3 months and desiccated to M.C. $16 \%$, to compare with seeds stored in wet conditions.

Finally, the relationship between seed M.C. and germination was investigated using seeds [Akita 2007] and [Akita 2008], and [Fukushima 2008]. These germination tests were conducted at $5^{\circ} \mathrm{C}$ after desiccation at $20^{\circ} \mathrm{C}$ for 2 months.

\section{Results}

\subsection{Germination in Different Temperatures and Light Conditions}

Seeds [Fukushima 2001] and [Fukushima 2002] showed lower germination rates immediately after seed collection (Figure 1 and Figure 2(a)). No seeds germinated at $20^{\circ} \mathrm{C}$ or $30^{\circ} \mathrm{C}$. The seeds from [Fukushima 2001] stored at $20^{\circ} \mathrm{C}$ for 1 or 3 months germinated at a rate of $50 \%$ to $60 \%$, respectively (Figure 1 ).

The seeds [Fukushima 2002] stored at $5^{\circ} \mathrm{C}$ for 3 months showed a germination rate of $37 \%$ only at $10^{\circ} \mathrm{C}$, which was half the germination rate of seeds stored at $20^{\circ} \mathrm{C}$ for 3 months (Figure $2(\mathrm{~b})$ ). These seeds did not germinate at $15^{\circ} \mathrm{C}$ or $20^{\circ} \mathrm{C}$ after storage at $5^{\circ} \mathrm{C}$, or at $25^{\circ} \mathrm{C}$ after storage at $20^{\circ} \mathrm{C}$ for 3 months (Figure 2(b)). Seeds stored at $20^{\circ} \mathrm{C}$ for 3 months (Figure 2(b)) and seeds stored at $5^{\circ} \mathrm{C}$ for 3 months after storage at $20^{\circ} \mathrm{C}$ for 3 months (Figure $2(\mathrm{c})$ ) showed a high germination rate of $60 \%$ at $10^{\circ} \mathrm{C}$. The germination rates of seeds kept at $10^{\circ} \mathrm{C}$ and $15^{\circ} \mathrm{C}$ after storage at $20^{\circ} \mathrm{C}$ for 3 months were not different from seeds stored at $5^{\circ} \mathrm{C}$ for 3 months, after storage at $20^{\circ} \mathrm{C}$ for 3 months (Figure $2(\mathrm{~b})$ and Figure 2(c)). As shown in Figure 7, although the germination rates were slightly different, the final percentage of germination was the same between seeds stored at $20^{\circ} \mathrm{C}$ for 1 months, then $10^{\circ} \mathrm{C}$ for 1 month, then moved to $5^{\circ} \mathrm{C}$, and seeds stored at $20^{\circ} \mathrm{C}$ for 1 month then moved to $10^{\circ} \mathrm{C}$. Thus, E. japonicum seeds germinate well at $5^{\circ} \mathrm{C}$ or $10^{\circ} \mathrm{C}$ after experiencing a warm temperature of $20^{\circ} \mathrm{C}$ for 3 months. 


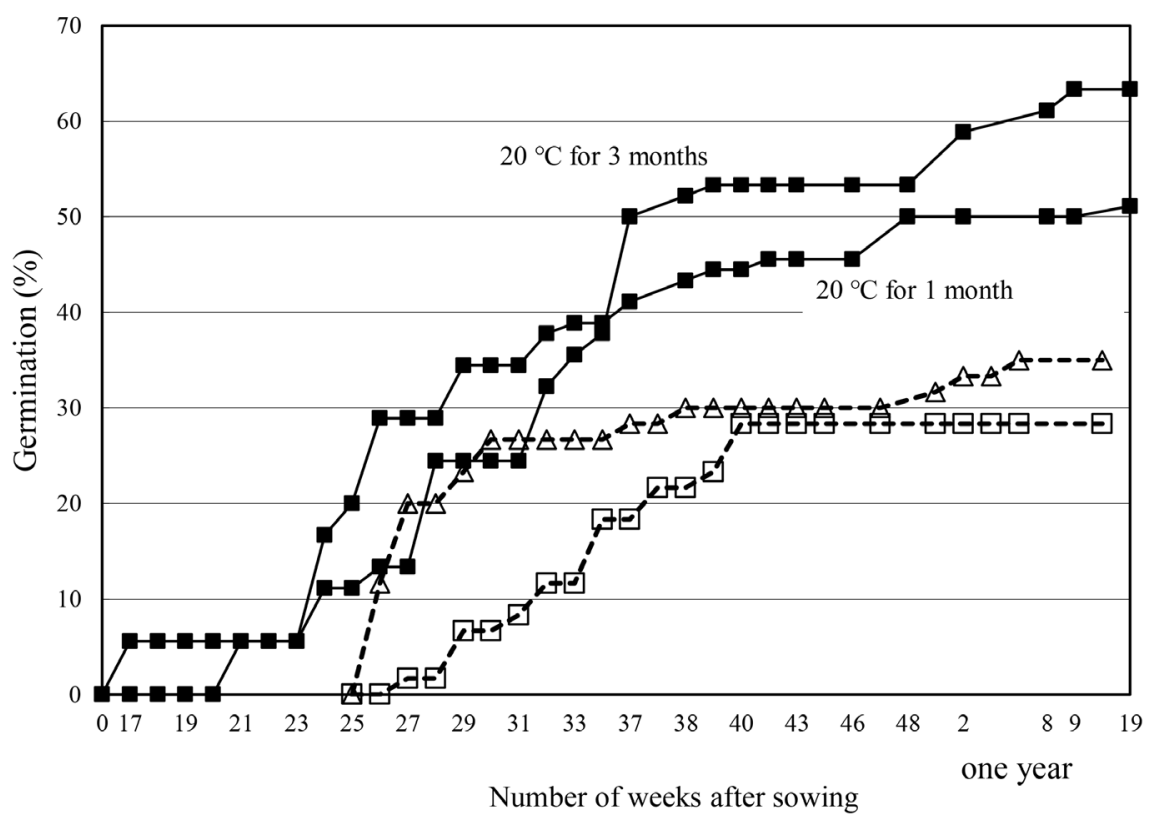

Figure 1. Germination curves for E. japonicum seeds [Fukushima 2001]. Seeds were stored in wetted perlite for "wet conditions" or a paper bag for "dry conditions" at room temperature $\left(20^{\circ} \mathrm{C}-25^{\circ} \mathrm{C}\right)$. Seed germination tests were conducted under light conditions at triangle $\Delta: 10^{\circ} \mathrm{C}$ and squares $-\& \square: 15^{\circ} \mathrm{C}$. The germination tests were done on just after seed collection (dotted line and white symbols), and begun on July 11, or Sep. 21 after storage in $20^{\circ} \mathrm{C}$ (line and black symbols). There was no experiment at $10^{\circ} \mathrm{C}$ after storage in $20^{\circ} \mathrm{C}$ under wet condition. Seed germination rate represents the average of three replicates. Seeds that did not germinate immediately after seed collection at $20^{\circ} \mathrm{C}$ or $25^{\circ} \mathrm{C}$. Seeds were stored for 1 month until July 11, 2001, and for 3 months until September 21, 2001 , did not germinate at $20^{\circ} \mathrm{C}$ or $25^{\circ} \mathrm{C}$. Seeds stored in dry conditions at room temperature showed 3 germination percentages at $10^{\circ} \mathrm{C}$.

However, seeds stored at $30^{\circ} \mathrm{C}$ showed half the germination rate of seeds stored at $20^{\circ} \mathrm{C}$ for 2 months after seed collection. Or seeds tested at $5^{\circ} \mathrm{C}$ immediately after collection showed little germination (Figure 3 ). The seeds tested at a monitoring temperature for the above leaf litter layer showed $8 \%$ germination rate, compared with seeds tested at a monitoring temperature for under the leaf litter layer, 33\% (Figure 4).

In these temperate experiments, the embryos grew at $20^{\circ} \mathrm{C}$ for 1 month, $10^{\circ} \mathrm{C}$ for 1 month, and then at $5^{\circ} \mathrm{C}$ (Figure 5 and Figure 6). As shown Figure 7, there was no difference in seed germination rate between light and dark conditions. The cotyledons grew until early May under monitoring leaf litter layer temperature from winter to spring after seed germination (Figure 8).

\subsection{Germination in Dry Conditions}

Desiccated seeds [Fukushima 2001] showed 3\% germination at $10^{\circ} \mathrm{C}$ after storage at room temperature, $20^{\circ} \mathrm{C}-25^{\circ} \mathrm{C}$ (Figure 1 ). Also, seeds desiccated to $16 \%$ M.C. did not germinate at temperatures of $10^{\circ} \mathrm{C}, 15^{\circ} \mathrm{C}, 20^{\circ} \mathrm{C}$, or $25^{\circ} \mathrm{C}$ after storage at $20^{\circ} \mathrm{C}$ for 3 months, as shown in Figure 2. The relationship between M.C. 

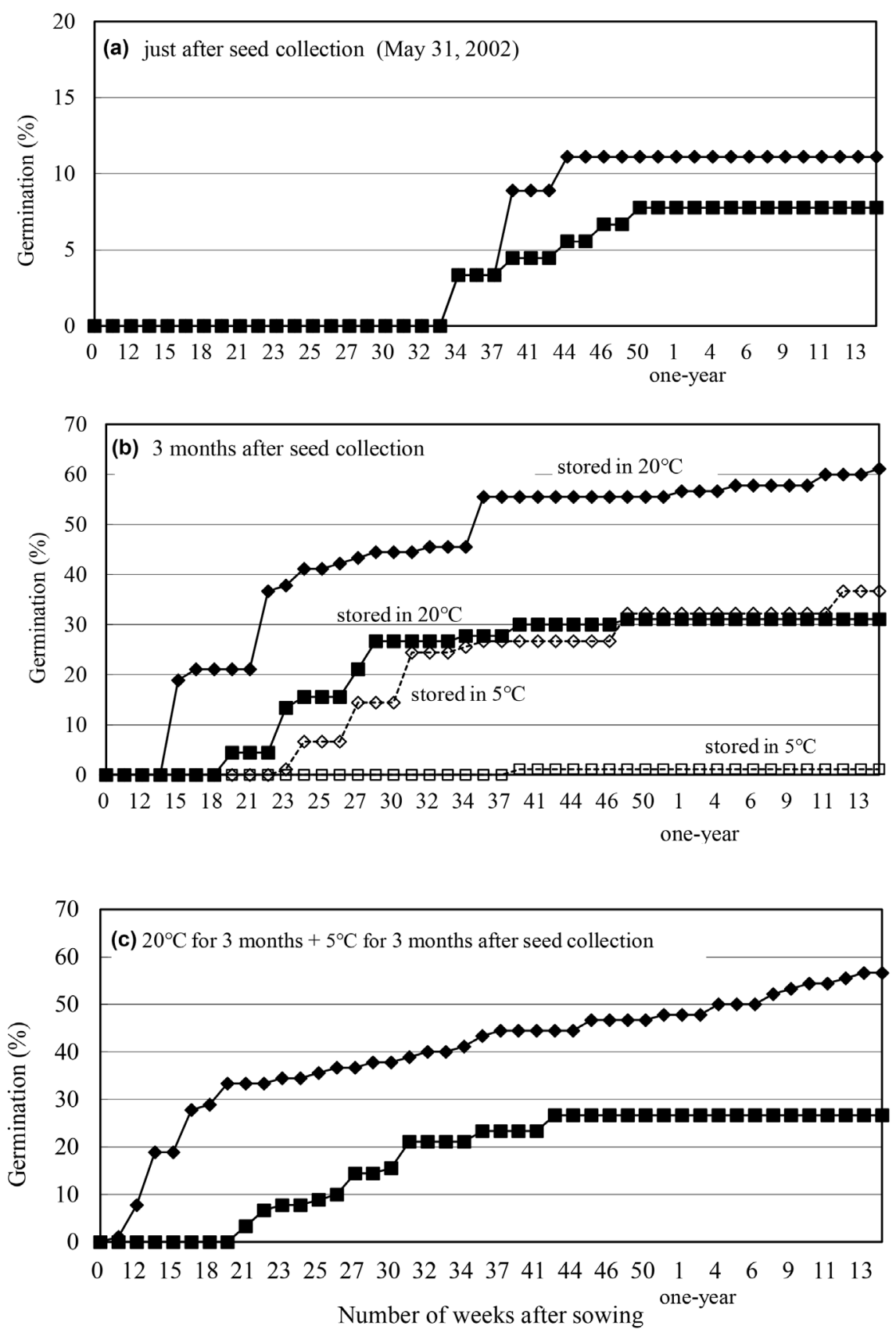

Figure 2. Germination curves for E. japonicum seeds. Seeds [Fukushima 2002] stored in wet conditions in a polyethylene bag. Seed germination tests were conducted under light conditions at $\bullet, \diamond: 10^{\circ} \mathrm{C}$ and $\bullet, \square: 15^{\circ} \mathrm{C}$. Not all seeds germinated at $20^{\circ} \mathrm{C}$ or $25^{\circ} \mathrm{C}$. The seed germination rates represent the average of three replicates. A: immediately after seed collection. B: seeds were stored at $5^{\circ} \mathrm{C}\left(\diamond, \square\right.$, and dotted line); at $20^{\circ} \mathrm{C}(\bullet, \mathbf{\bullet}$, and line) for 3 months. The seeds did not germinate at $15^{\circ} \mathrm{C}$ and $20^{\circ} \mathrm{C}$ after storage at $5^{\circ} \mathrm{C}$, and at $25^{\circ} \mathrm{C}$ after storage at $20^{\circ} \mathrm{C}$ for 3 months. Seeds dried to $16 \%$ moisture content did not germinate at $10^{\circ} \mathrm{C}, 15^{\circ} \mathrm{C}, 20^{\circ} \mathrm{C}$ or $25^{\circ} \mathrm{C}$ after storage at $20^{\circ} \mathrm{C}$. C: seeds stored at $5^{\circ} \mathrm{C}$ until testing (November 25, 2002) in addition to storage at $20^{\circ} \mathrm{C}$ until August 12, 2002.

and seed germination rate for the three kinds of seeds source showed that seeds decreased and lost germinability at less than $60 \%$ and $40 \%$ M.C., respectively (Figure 9). 


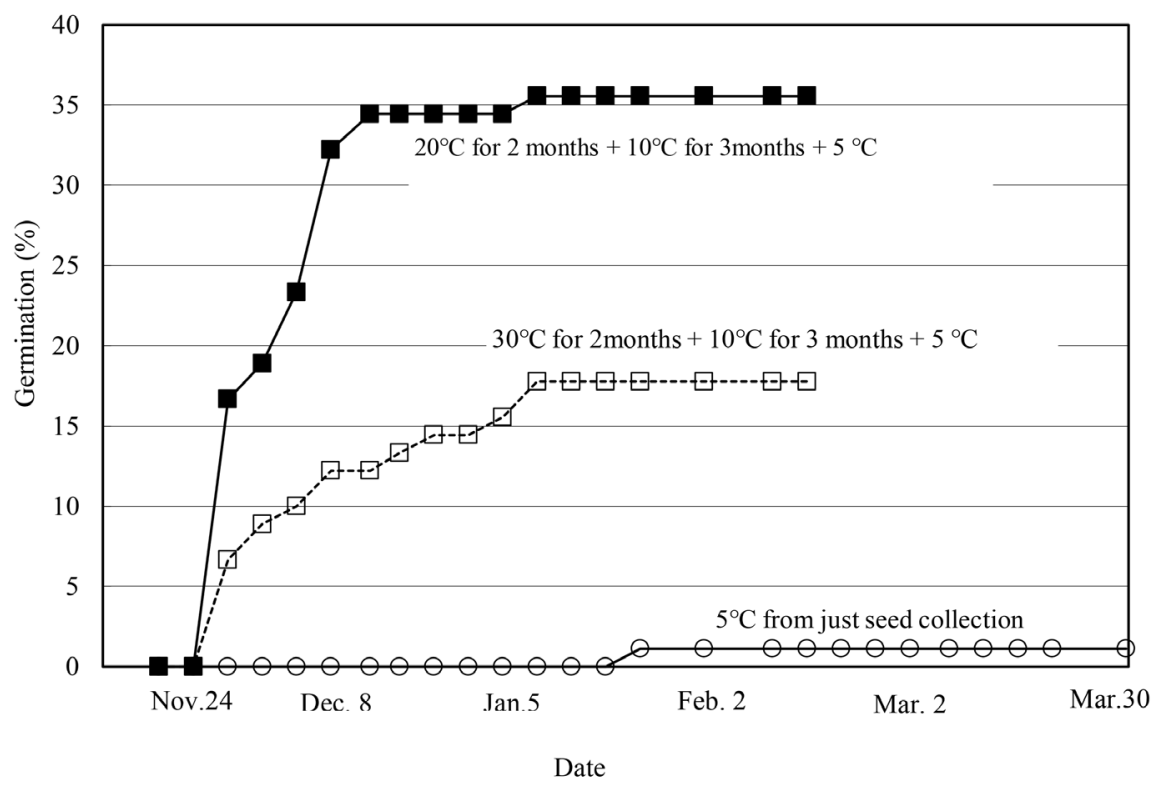

Figure 3. Germination curves for E. japonicum seeds [Akita 2005]. Germination tests were conducted $\mathrm{O}$ : at $5^{\circ} \mathrm{C}$ immediately after collection; -: at $5^{\circ} \mathrm{C}$ after storage at $20^{\circ} \mathrm{C}$ from seed collection (June 30) to August 29, followed by $10^{\circ} \mathrm{C}$ from August 29 to November 26,2005 and $\square$ : at $5^{\circ} \mathrm{C}$ after storage at $30^{\circ} \mathrm{C}$ from seed collection (June 30) to August 29, and $10^{\circ} \mathrm{C}$ from August 29 to November 26, 2005.

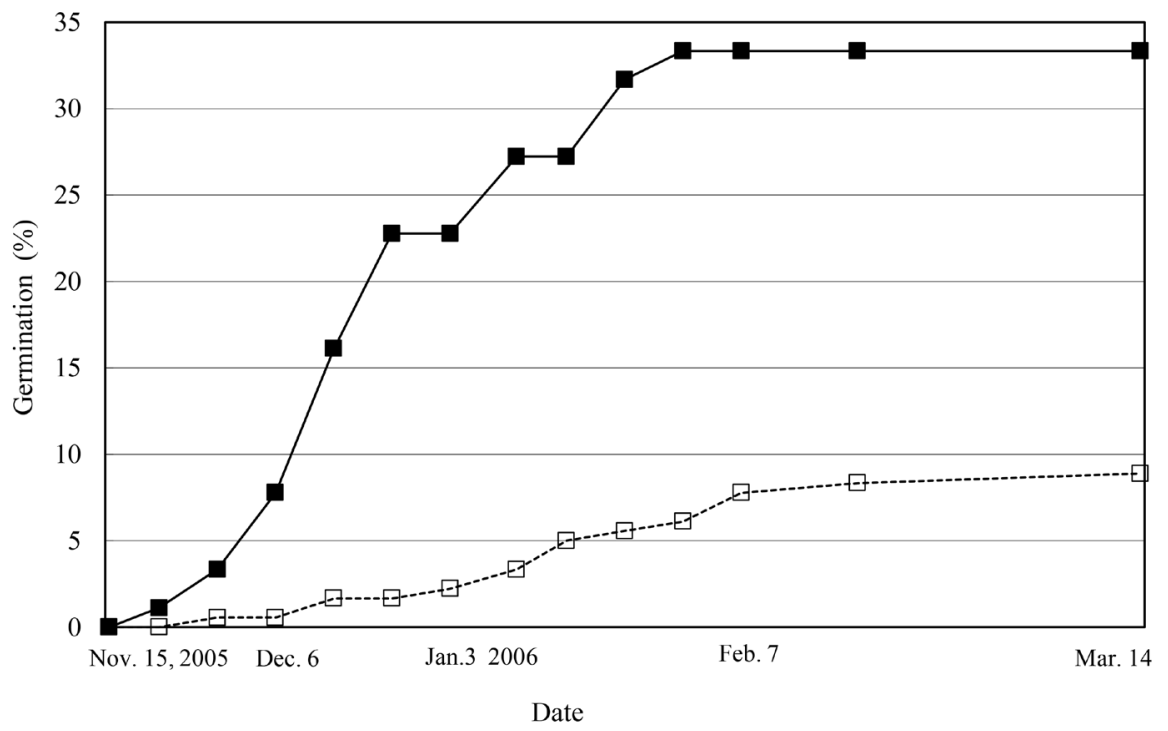

Figure 4. Germination curves at different temperatures for E. japonicum seeds [Akita 2005]. -: monitoring temperature as below the leaf litter layer; $\square$ : monitoring temperature as above the leaf litter layer.

\section{Discussion}

E. japonicum seeds need a temperature of about $20^{\circ} \mathrm{C}$ during the 3 months before germination at $5^{\circ} \mathrm{C}$ to $10^{\circ} \mathrm{C}$. Seed germination rates were low at the monitoring above leaf litter layer temperature and high temperature $\left(30^{\circ} \mathrm{C}\right)$ experience for 2 months immediately after seed collection. Seeds that were 


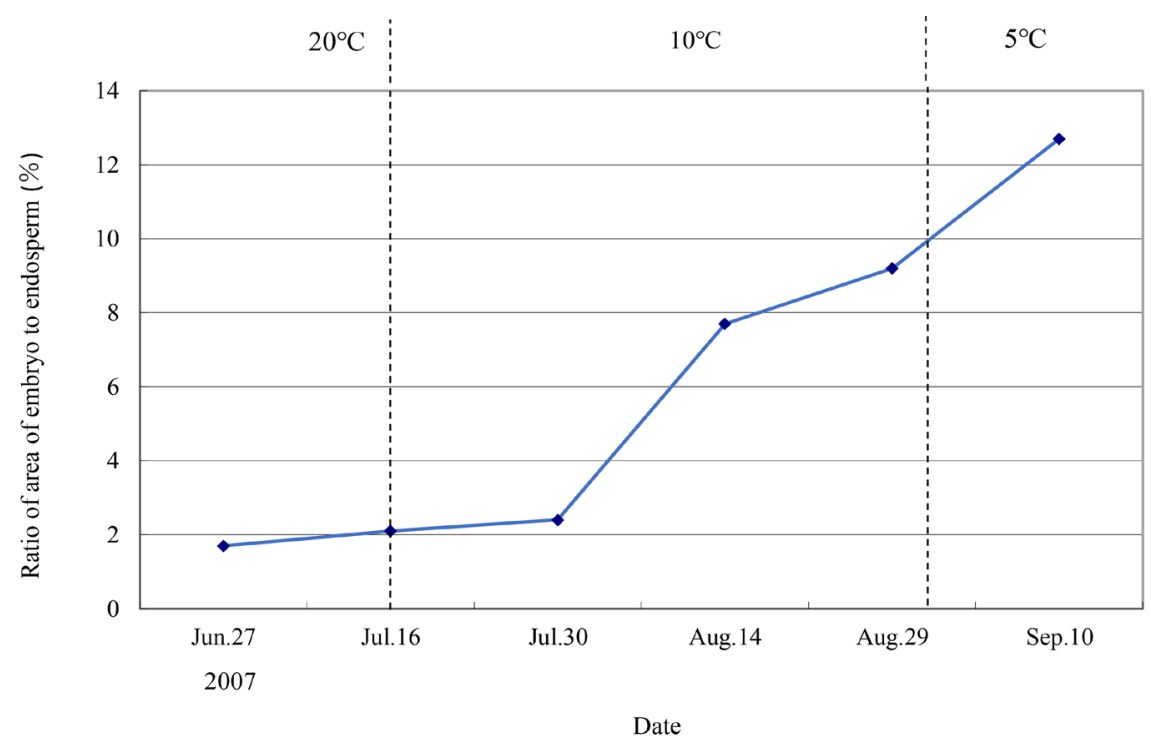

Figure 5. The ratio of embryo to endosperm (\%) during storage at $20^{\circ} \mathrm{C}$ for 1 month, $10^{\circ} \mathrm{C}$ for 1 month, and at $5^{\circ} \mathrm{C}$ in seeds [Akita 2007].
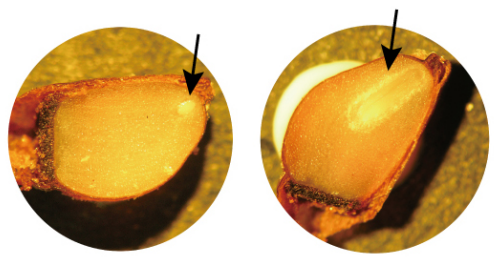

Figure 6. Embryo (arrows) in seeds stored in $20^{\circ} \mathrm{C}$ for 1 month (left), and after $20^{\circ} \mathrm{C}$ for 1 month and $10^{\circ} \mathrm{C}$ for 1 month (right) of seeds [Akita 2007].

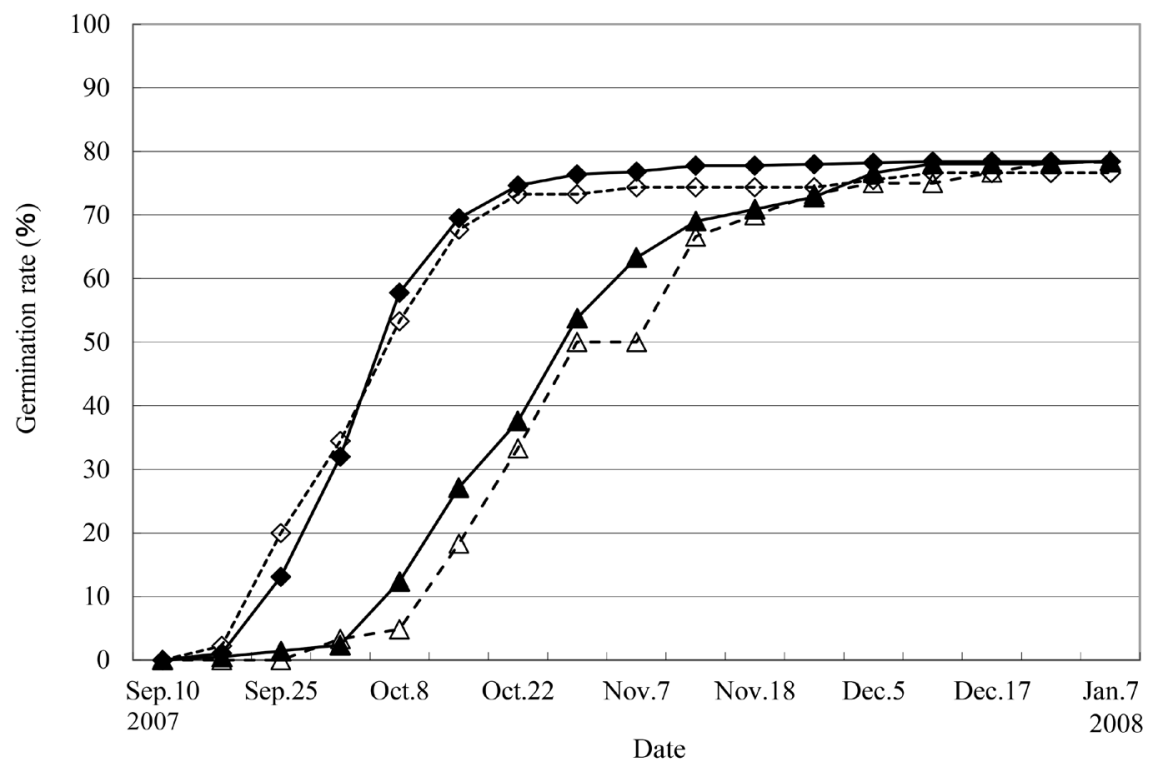

Figure 7. Germination curves at different temperatures and light conditions for E. japonicum seeds [Akita 2007]. Line is light and dotted line is dark conditions. Seeds were stored at $20^{\circ} \mathrm{C}$ for 1 month, $10^{\circ} \mathrm{C}$ for 1 month, and then moved to $5^{\circ} \mathrm{C}\left(\bullet\right.$ and $\diamond$ ); $20^{\circ} \mathrm{C}$ for 1 month, and then moved to $10^{\circ} \mathrm{C}(\boldsymbol{\Delta}$ and $\Delta)$. 


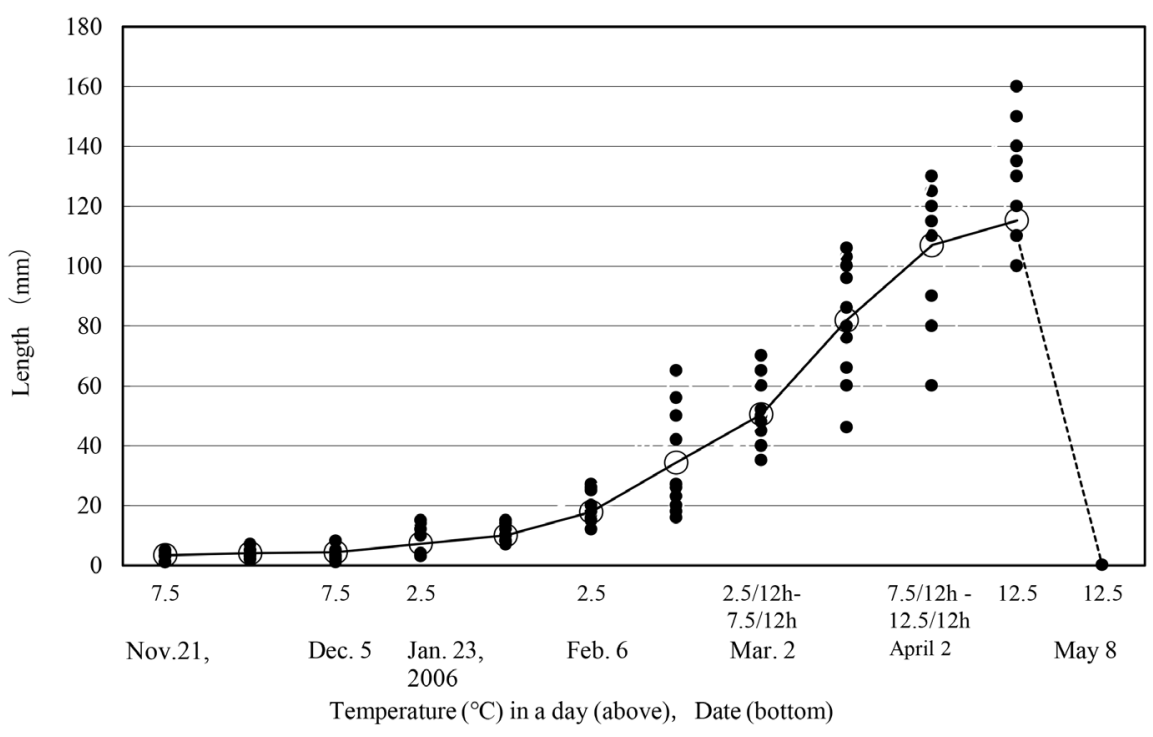

Figure 8. Radicle length after germination in E. japonicum seeds [Akita 2005]. The radicle disappeared on May 8, 2006. O: average; $\bullet$ : individual data points.

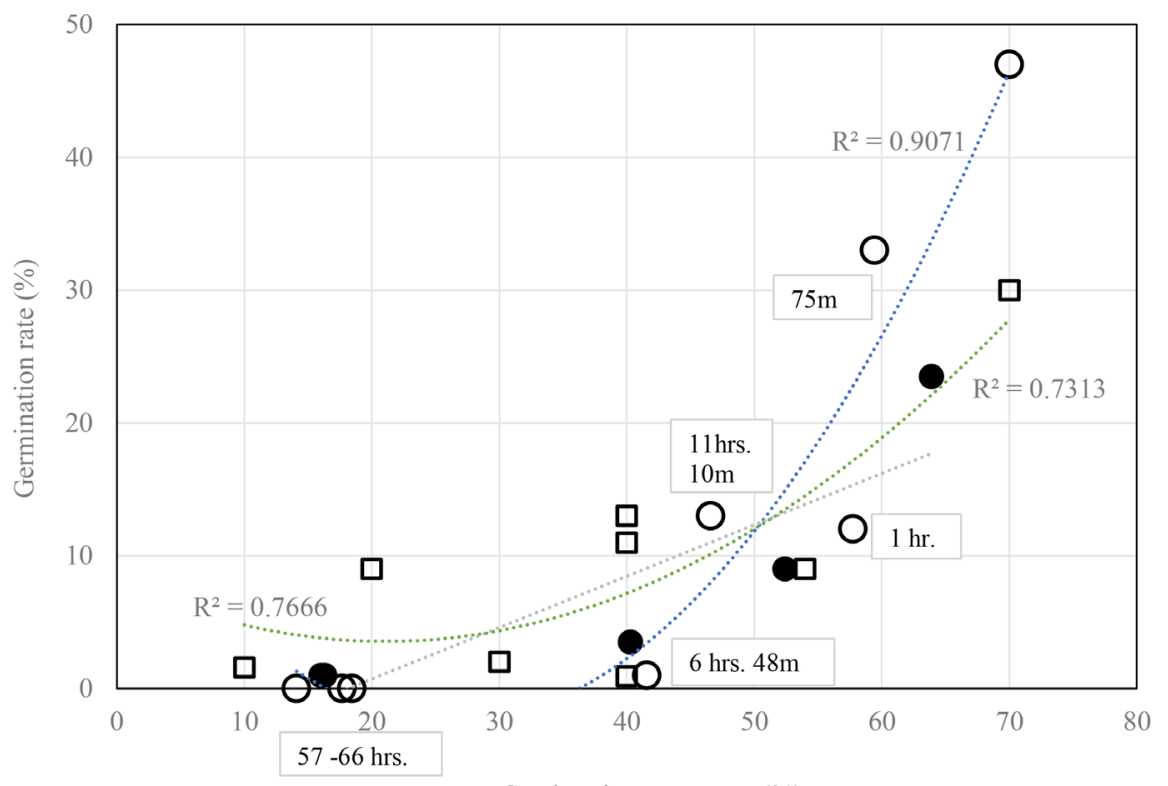

Seed moisture content (\%)

Figure 9. Relationships between moisture content and germination rate. Seeds for experiments were [Akita 2007] (O), at [Akita 2008] ( $\square$ ), and [Fukushima 2008] (•). Number is hour(s) and minutes after seed desiccation for seeds [Akita 2007] (O).

maintained at $5^{\circ} \mathrm{C}$ after seed collection also did not germinate. Embryos developed at $10^{\circ} \mathrm{C}$ after storage at $20^{\circ} \mathrm{C}$ for 1 month. These results showed that $E$. japonicum seeds germinated well at $5^{\circ} \mathrm{C}-10^{\circ} \mathrm{C}$ after experiencing $20^{\circ} \mathrm{C}$. Even though M.C. was $40 \%$, the seeds rapidly lost germinability. Under light and dark conditions, there was no difference in seed germination.

The surface below the leaf litter layer, where many seeds are dispersed by myrmecochory, has specific temperatures, light (dark), and moisture conditions: 
1) temperature under the leaf litter layer was below $25^{\circ} \mathrm{C}$, even in the summer when the temperature above was about $35^{\circ} \mathrm{C} ; 2$ ) temperature under the leaf litter layer in the winter remained at $2^{\circ} \mathrm{C}-4^{\circ} \mathrm{C}$, even when the temperature above was below $0^{\circ} \mathrm{C}$ (Suzuki \& Kawano, 2010); 3) high moisture content was maintained under the leaf litter layer even when it was dry above the leaf litter layer (Suzuki, 2006; Young \& Evans, 1989); 4) it was dark under the leaf litter layer, since the sunlight was obstructed by the leaf litter (Suzuki, 2006), or plots with leaf litter had significantly lower light levels at the soil surface than those with no litter (Reynolds et al., 2001).

Almost fruits or seeds are fructified in autumn in Japan. E. japonicum is a representative species of spring ephemerals in forest floor plants. Fruits or seeds of E. japonicum are fructified in late spring or early summer, from late May to early June. E. japonicum seeds are heavy with high moisture content on the just after fructification (2.7 g/100 seeds, M.C. 65.3\%, Suzuki, 2006). Myrmecochory is when seeds with an elaiosome are dispersed by ants or ground beetles (Culver \& Beattue, 1978; Ohara \& Higashi, 1987). Many seeds became submerged under the leaf litter over time. We observed seeds that fell under the leaf litter layer at the time when ants or ground beetles eat elaiosomes, or when the leaf litter was disturbed by rain or wind. When we sieved the seeds and leaf litter, even broadly through fingers, these seeds fell under the leaf litter. We also observed the radicle of E. japonicum under the leaf litter, and the cotyledon growing through the litter when it emerged (Suzuki, 2013). These results showed that E. japonicum seeds were dispersed under the leaf litter layer.

The temperature $\left(20^{\circ} \mathrm{C}\right)$ needed to promote germination of E. japonicum seeds matched the temperature under the leaf litter layer, but not the temperature above; thus, germinability was reduced. Such a decrease in germinability from such a small loss in seed moisture content and over such a short time is coincident with the moisture conditions above the leaf litter layer. The leaf litter layer maintains the seed moisture content and germinability. Although there is no light under the leaf litter layer, E. japonicum seeds can germinate in the dark. Consequently, the seedlings in early spring, late May to early April, under natural conditions are those that germinated under and broke through the leaf litter layer.

The relationships between temperature, light, and moisture conditions in the leaf litter layer and germination of E. japonicum follow those for Trillium apetaIon Makino (Suzuki \& Kawano, 2010). These may be the general germination characteristics of spring ephemerals.

Many species of forest floor plants, Heterotropa muramatsui (Makino) F. Maek. (Asarum muramatsui Makino), E. japonicum, and Cephalanthera falcata (Thunb.) Blume etc. have recently been listed in the Red Data Book. Spring ephemerals have a unique life history in the specific temperature, light, and moisture conditions of the leaf litter. As a representative spring ephemeral species, $E$. japonicum, takes more than 8 years to produce flowers (Kawano et al., 1982; Kawano, 2004). Therefore, it is more difficult to maintain habitat for $E$. 
japonicum over a long time in warm-temperate zones. Previously, people managed the forest floor, e.g. cutting shrubs and Pleioblastus chino Makino (Nakajima et al., 2017), and gathering leaves. Moreover, these plants show unique seed germination habits. Warm temperatures which do not reach $30^{\circ} \mathrm{C}$ in summer, and high seed moisture content facilitate germinability. Leaf litter is very important for the germination of E. japonicum seeds. There are some discussions about the role of leaf litter in seed germination (Baskin \& Baskin, 2014). When we collected leaf litter in one of the areas for one winter to make compost, there was no influence on germination, since areas of coppiced forest were substantial in the past. However, careful maintenance is needed to maintain forest floor plants in the small areas of fragmented and isolated remaining forests now. To artificially propagate $E$. japonicum, we need to confirm the role of leaf litter in germination.

For the sustainable development of forests, or to benefit from sustainable forest management, we need to maintain enough natural open spaces in suburban areas. It is beneficial to grow forest floor plants to create landscapes, evaluate their recreational functions, and admire natural landscapes (open spaces).

\section{Acknowledgements}

We are grateful to Mr. Toshiyuki Suzuki and Mr. Gensaku Sato, at incorporated foundation Urban park and Green society in Fukushima prefecture, Mr. Masami Ogura, Miharu Katakuri no Sato (Miharu E. japonicum village) in Fukushima Prefecture, and Mr. Yoshinori Sasaki, Village of Katakuri (E. japonicum) colonies, Nishiki town, Senboku city, Akita Prefecture, their help of seed collection in the field. We also would like to thank Editage (http://www.editage.jp/) for English language editing.

\section{References}

Association of Wildlife Research and EnVision (2007). Search System of Japanese Red Data.

http://jpnrdb.com/search.php? mode=spec\&q=\%E3\%82\%AB\&subn=\&k=06\&pageID=3

Baskin, C. C., \& Baskin, M. J. (2014). Seeds (2nd ed., pp. 788-792). San Diego, CA: Academic Press.

Culver, C. D., \& Beattue, J. A. (1978). Myrmecochory in Viola: Dynamics of Seed-Ant Interactions in Some West Virginia Species. Journal of Ecology, 66, 53-72. https://doi.org/10.2307/2259181

Iida, S., \& Nakashizuka, T. (1995). Forest Fragmentation and Its Effect on Species Diversity in Sub-Urban Coppice Forests in Japan. Forest Ecology and Management, 73, 197-210. https://doi.org/10.1016/0378-1127(94)03484-E

Kawano, S. (Ed.). (2004). Life History Monographs of Japanese Plants (Volume 1, pp. 1-8). Sapporo, Hokkaido: Hokkaido University Press.

Kawano, S., Hiratsuka, A., \& Hayashi, K. (1982). The Productive and Reproductive Biology of Flowering Plants V. Life History Characteristics and Survivorship of Erythronium japonicum. Oikos, 38, 129-149. https://doi.org/10.2307/3544013

Morimoto, Y. (2011). What Is Satoyama? Points for Discussion on Its Future Direction. 
Landscape \& Ecological Engineering, 7, 163-171.

https://doi.org/10.1007/s11355-010-0120-5

Nakajima, H., Kojima, H., Tachikawa, K., Suzuki, K., \& Rotherham, D. I. (2017). Ecological and Growth Characteristics of Trees after Resumption of Management in Abandoned Substitution Forest in Japan. Landscape and Ecological Engineering. (In Print)

Nakajima, H., Suzuki, K., \& Kameyama, Y. (2016). Changes in Forest Floor Vegetation after the Mowing of Pleioblastus chino: A Case Study from an Abandoned Coppice Forest in the Kanto Region of Japan. Japanese Journal of Conservation Ecology, 21, 51-60. (In Japanese with English Summary)

Ohara, M., \& Higashi, S. (1987). Interference by Ground Beetles with the Dispersal by Ants of Seeds of Trillium species (Liliaceae). Journal of Ecology, 75, 1091-1098.

https://doi.org/10.2307/2260316

Reynolds, S. A., Corbin, J. D., \& D’Antonio, C. M. (2001). The Effects of Litter and Temperature on the Germination of Native and Exotic Grasses in a Coastal California Grassland. Madrono, 48, 230-235.

Stéphanie, D., Felix, E., \& Lenore, F. (2007). Effects of Surrounding Urbanization on Non-Native Flora in Small Forest Patches. Landscape Ecology, 22, 589-599.

https://doi.org/10.1007/s10980-006-9050-x

Suzuki, K. (2006). Studies on the Reproductive Strategies of Japanese Liliaceous Plants by Seeds. Journal of Landscape Architecture, Extra Issue 10, 127 p.

Suzuki, K. (2013). Environmental Conditions after Seed Dispersal of Spring Ephemeral Species at the Floor of Deciduous, Broad-Leaved Forests. In C. A. Busso (Ed.), From Seed Germination to Young Plants: Ecology, Growth and Environmental Influences (pp. 329-339). New York: NOVA Science Publishers, Inc.

Suzuki, K., \& Kawano, S. (2010). Seed Germination and Dispersal Strategy of Trillium apetalon (Trilliaceae): A Typical Temperate Woodland Perennial in Japan. Plant Species Biology, 25, 231-239. https://doi.org/10.1111/j.1442-1984.2010.00295.x

Yokohari, M., \& Bolthouse, J. (2011). Keep It Alive, Don't Freeze It: A Conceptual Perspective on the Conseration of Continuously Evolving Satoyama Landscapes. Landscape \& Ecological Engineering, 7, 207-216. https://doi.org/10.1007/s11355-010-0116-1

Young, J. A., \& Evans, R. A. (1989). Seed Production and Germination Dynamics in California Annual Grasslands. In: L. F. Huenneke, \& H. A. Mooney (Eds.), Grassland Structure and Function. California Annual Grassland (pp. 39-45). Dordrecht: Kluwer. https://doi.org/10.1007/978-94-009-3113-8_4 